\title{
Characterization of sewage sludge generated in Rio de Janeiro, Brazil, and perspectives for agricultural recycling
}

\section{Caracterização do lodo de esgoto gerado no Rio de Janeiro, Brasil, e perspectivas para reciclagem agrícola}

\author{
Alan Henrique Marques de Abreu ${ }^{1 *}$; Paulo Sérgio dos Santos Leles ${ }^{2}$; Jorge \\ Makhlouta Alonso ${ }^{1}$; Elton Luis da Silva Abel ${ }^{1}$; Ricardo Rodrigues de Oliveira ${ }^{3}$
}

\begin{abstract}
Sanitary sewage collection and treatment is a serious environmental problem in Brazilian cities, as well as the destination of solid waste resulting from this process, i.e. the sewage sludge, a substance rich in organic matter and nutrients, which is normally discarded in landfills. The aim of this study was to characterize the sewage sludge generated in four treatment stations in Rio de Janeiro State, Brazil and check if they meet the legal criteria of the National Environment Council (CONAMA), Resolution No. 375/2006. It also focused on analyzing the perspectives for its agricultural recycling based on the potential demand for main agricultural crops grown in Rio de Janeiro State. Samples from eight sewage sludge lots from four treatment stations located in the metropolitan area of Rio de Janeiro were analyzed. These stations receive and treat only domestic sewage by activated sludge system. For chemical and biological characterization of these lots, representative samples were collected and analyzed according to parameters of CONAMA Resolution No. 375/2006. In order to analyze the perspectives of agricultural recycling of sewage sludge in Rio de Janeiro State, 10 crops with the largest cultivated area in the state were surveyed and analyzed which of them are apt to receive sewage sludge as fertilizer and/or soil amendment. To determine the potential demand for sewage sludge in agriculture, the area occupied by these crops were multiplied by each fertilizer recommendation considering the sewage sludge as fertilizer. The analyzed sludge presented a high content of nutrients and organic matter and was included in the parameters of heavy metals, pathogenic agents, and bacteriological indicators stipulated by CONAMA Resolution No. 375/2006. The agricultural panorama of Rio de Janeiro State is favorable for agricultural recycling of sewage sludge since there is a great potential demand for this residue and, among the 10 agricultural crops with the largest cultivated area in the state, sludge can be used as fertilizer or soil amendment in eight of them. The implementation of a State Sewage Sludge Recycling Program could dispose of this material in a more sustainable way, as well as improve the quality of agricultural soils and reduce costs with chemical fertilizers, bringing positive results for sanitation companies and producers.
\end{abstract}

Key words: Biosolid. Solid waste. Organic fertilization.

\section{Resumo}

A coleta e tratamento do esgoto sanitário é um grave problema ambiental nas cidades brasileiras, bem

' Discentes, Curso de Doutorado, Programa de Pós-Graduação em Ciências Ambientais e Florestais, Universidade Federal Rural do Rio de Janeiro, UFRRJ, Seropédica, RJ, Brasil. E-mail: alanhenriquem@gmail.com; j_makh@hotmail.com; elton@cedae. com.br

2 Prof. Titular, UFRRJ, Seropédica, RJ, Brasil. E-mail: pleles@ufrrj.br

3 Discente, Curso de Graduação em Engenharia Florestal, UFRRJ, Seropédica, RJ, Brasil. E-mail: richardzoo@ufrrj.br

* Author for correspondence

Received: Nov. 17, 2016 Approved: Feb. 09, 2017 
como a destinação do resíduo sólido resultante desse processo, o lodo de esgoto, substância rica em matéria orgânica e nutrientes, que normalmente é descartada em aterros sanitários. Objetivou-se com este trabalho caracterizar o lodo de esgoto gerado em quatro estações de tratamento do estado do Rio de Janeiro e verificar se os mesmos atendem aos critérios legais presentes na resolução CONAMA n³75/2006. Com o trabalho visa-se ainda analisar as perspectivas para a reciclagem agrícola deste material, com base na demanda potencial das principais culturas agrícolas cultivadas no estado do Rio de Janeiro. Foram analisadas amostras de oito lotes de lodo de esgoto, oriundos de quatro estações de tratamento, localizadas na região metropolitana do Rio de Janeiro, que recebem e tratam apenas esgotos domésticos, pelo sistema de lodos ativados. Para caracterização química e biológica desses lotes coletaram-se amostras representativas que foram analisadas segundo os parâmetros contidos na Resolução n 375/2006 do CONAMA. Para analisar as perspectivas de reciclagem agrícola do lodo de esgoto no estado do Rio de Janeiro, foram levantadas as 10 culturas com maior área plantada no estado e analisadas quais destas são aptas a receberem o lodo de esgoto como fertilizante e/ou condicionador de solos. Para determinação da demanda potencial de uso do lodo de esgoto na agricultura foi levado em consideração a área ocupada no estado pelas culturas aptas a receber o lodo e multiplicado pela recomendação de adubação da cultura, considerando o lodo de esgoto como fertilizante. Os lodos analisados apresentaram elevado teor de nutrientes e matéria orgânica e enquadraram-se nos parâmetros de metais pesados, agentes patogênicos e indicadores bacteriológicos estipulados pela resolução CONAMA n ${ }^{\circ} 375 / 2006$. O panorama agrícola do estado do Rio de Janeiro se mostra favorável para a reciclagem agrícola do lodo de esgoto, visto que existe uma grande demanda potencial e dentre as dez culturas agrícolas com maior área plantada no estado, em oito pode-se utilizar o lodo como fertilizante ou condicionador de solos. A implementação de um Plano Estadual de reciclagem do lodo de esgoto poderia dispor este material de forma mais sustentável, além de melhorar a qualidade dos solos agrícolas e diminuir os custos com fertilizantes químicos, o que traz reflexos positivos tanto para as empresas geradoras de lodo, como para os produtores rurais.

Palavras-chave: Biossólido. Resíduos sólidos. Adubação orgânica.

\section{Introduction}

A sewage treatment station (STS) provides an important environmental service to society by collecting and treating millions of liters of sewage daily, thus avoiding that considerable organic load reaches water bodies. After treatment, water is returned to springs, remaining in the stations the solid waste called sewage sludge (ABREU, 2014).

In Brazil, only $49.8 \%$ of sewage is collected, being treated $70.9 \%$ of this sewage (BRASIL, 2016). In regions with better sanitation conditions, the final disposal of residues from sewage treatment is a matter of concern. In Rio de Janeiro State alone, about 365 tons of sewage sludge is produced per day, totaling 133,225 tons per year, being disposed of in landfills almost all of it (PERS, 2014). However, this scenario tends to change firstly due to society's increased environmental awareness, which demands that the National Solid Waste Policy (BRASIL, 2010) be duly complied with allocating residues in a more sustainable way. Secondly, due to the difficulty of opening new landfills and outsourcing or closing public landfills, which has raised the cost of disposal of these residues to STSs (BIELSCHOWSKY, 2014).

This material has in its composition high contents of nutrients and organic matter that could be reused, increasing crop productivity and decreasing the dependence on chemical fertilizers (CHIBA et al., 2008; LOBO et al., 2015; LOZADA et al., 2015). In some countries, such as the United States, Australia, France, the United Kingdom, and Spain, agricultural recycling of sludge is widespread, with some regions disposing up to $80 \%$ of the sludge generated at their stations for soil applications (BOURIOUG et al., 2015; LU et al., 2012; MININNI et al., 2015; PRITCHARD et al., 2010). In Brazil, the main form of final disposal of sewage sludge has still been by means of landfills, despite its great potential for agricultural use. 
Agricultural recycling can be an environmentally correct alternative to disposing of this residue, with advantages for STSs, which dispose of their residues in a more sustainable way, and producers, who receive a material rich in nutrients and organic matter. However, before implementing a sewage sludge recycling program, the composition of the generated material in STSs needs to be known and verified whether it comply with the current legislation and meet the regional demand thus justifying this alternative.

Based on the above, the aim of this study was to characterize chemically and biologically the sewage sludge generated in four treatment stations of the metropolitan region of Rio de Janeiro, Brazil. Also, it focused on verifying whether it meets CONAMA Resolution No. 375/2006 and analyzing the perspectives for its agricultural recycling, based on the potential demand to attend the fertilization requirements of agricultural crops grown in Rio de Janeiro State.

\section{Material and Methods}

Samples from eight sewage sludge lots from four STSs that receive and treat only domestic sewage and are located in the metropolitan area of Rio de Janeiro were analyzed. These STSs are operated and maintained by the State Water and Sewage Company of Rio de Janeiro (CEDAE). They have the following treatment processes: STS Alegria $\left(5,000 \mathrm{~L} \mathrm{~s}^{-1}\right)$ and STS Ilha do Governador (535 $\mathrm{L} \mathrm{s}^{-1}$ ), a secondary treatment with activated sludge system, biological anaerobic stabilization, centrifugal dewatering, and drying in semipermeable beds; STS Sarapuí $(1,500$ $\mathrm{L} \mathrm{s}^{-1}$ ), a secondary treatment with activated sludge system, centrifugal dewatering, and thermal drying; and STS Barra da Tijuca $\left(1,600 \mathrm{~L} \mathrm{~s}^{-1}\right)$, a primary treatment with centrifugal dewatering and thermal drying.

CEDAE has an internal sewage sludge recycling project to produce Atlantic Forest seedlings in its forest nurseries. Therefore, the analyzed lots coincided with the need for analysis by this project. The lots analyzed were: I-STS Alegria, December 2012; II-STS Alegria, November 2014; III-STS Barra da Tijuca, August 2013; IV-STS Ilha do Governador, November 2014; V-STS Ilha do Governador, February 2015; VI-STS Ilha do Governador, January 2016; VII-STS Sarapuí, August 2013; and VIII-STS Sarapuí, November 2014.

For characterizing and assessing the agronomic potential of sludge lots from different STSs, representative samples of materials were collected and analyzed chemically and biologically according to standards contained in Annex IV of CONAMA Resolution No. 375/2006 (BRASIL, 2006). Thus, for total $\mathrm{N}$ determination, the Kjeldahl method was used, in which $0.05 \mathrm{~g}$ of oven-dried sample (65 ${ }^{\circ} \mathrm{C}$ ) was diluted in $3 \mathrm{~mL}$ of concentrated $\mathrm{H}_{2} \mathrm{SO}_{4}$. Subsequently, this solution was led to a digester block at $360{ }^{\circ} \mathrm{C}$ for $3 \mathrm{~h}$. For distillation, $20 \mathrm{~mL}$ $\mathrm{NaOH}$ solution $\left(10 \mathrm{~mol} \mathrm{~L}^{-1}\right)$ was added. Distilled $\mathrm{N}$ was added to $20 \mathrm{~mL} \mathrm{H}_{3} \mathrm{BO}_{3}$ solution $\left(20 \mathrm{~g} \mathrm{~L}^{-1}\right)$, which was titrated with a standard $\mathrm{H}_{2} \mathrm{SO}_{4}$ solution $\left(0.0025 \mathrm{~mol} \mathrm{~L}^{-1}\right)$.

The elements $\mathrm{P}, \mathrm{K}, \mathrm{Ca}, \mathrm{Mg}, \mathrm{As}, \mathrm{Ba}, \mathrm{Cd}, \mathrm{Cr}$, $\mathrm{Cu}, \mathrm{Hg}, \mathrm{Ni}, \mathrm{Pb}, \mathrm{Se}$, and $\mathrm{Zn}$ were extracted in a microwave oven by using the SW-846 test method 3051 (USEPA, 2010). Samples of $0.5 \mathrm{~g}$ of sewage sludge were oven dried at $65{ }^{\circ} \mathrm{C}$ and mixed in 10 $\mathrm{mL}$ of concentrated nitric acid. After 15 minutes, samples were placed in a microwave oven for 30 minutes. $\mathrm{K}$ determination was performed by flame photometry and the other elements by atomic emission spectrometry by inductively coupled plasma (ICP-AES).

Organic matter was defined by organic carbon content, which was determined by the Walkley and Black method, being subsequently multiplied by the van Bemmelen factor, equivalent to 1,724 (CARMO; SILVA, 2012). The value of $\mathrm{pH}$ was determined using a sample of $2 \mathrm{~g}$ of sewage sludge diluted in $20 \mathrm{~mL}$ of deionized water, shaken for 5 
minutes on a horizontal circular shaker at $200 \mathrm{rpm}$. After 30 minutes of rest, $\mathrm{pH}$ was determined by means of a bench $\mathrm{pH}$ meter.

Microbiological characterization of sewage sludge for the presence of thermotolerant coliforms, viable eggs of helminths, and Salmonella sp., which correspond to the presence of harmful pathogens to human health, was carried out by a specialized laboratory. This characterization was performed according to US EPA part503 (2003), as stipulated by CONAMA Resolution No. 375/2006 (BRASIL, 2006). Through these analyses, sewage sludge can be classified into class A (excellent quality) or B (greater restrictions of use) depending on the presence and/or concentrations of microorganisms in its composition. Enteric virus parameter was not assessed due to the difficulty of finding a laboratory that performed this analysis. Microbiological and heavy metal parameters were compared to the maximum allowed by CONAMA Resolution No. 375/2006 (BRASIL, 2006) and assessed whether they comply with the current legislation on sludge application to soil.

In order to analyze the perspectives for agricultural recycling of sewage sludge in Rio de Janeiro State, data based on the year 2014 from the Systematic Survey of Agricultural Production, prepared and made available by the Technical Assistance and Rural Extension Company (EMATER) of Rio de Janeiro, were used. The 10 agricultural crops with the largest cultivated area in Rio de Janeiro State were surveyed and analyzed regarding their aptitude to receive sewage sludge as fertilizer and/or soil amendment, according to the Article 12 of CONAMA Resolution No. $375 / 2006$. To determine the potential demand for sewage sludge, the area occupied by these crops were multiplied by the fertilizer recommendation considering the sewage sludge as fertilizer for each crop, obtained in the literature. When more than one recommendation was found, the average of them was taken into account for calculation.

\section{Results and Discussion}

The high content of nutrients in the sewage sludge lots (Table 1) corroborates the results by diverse authors. Those of Aguilera et al. (2007) who characterized the sludge from three STSs in Chile; MTSHALI et al. (2014) who analyzed the sludge from seven STSs in Swaziland (Southern Africa); and Carvalho et al. (2015) who analyzed five different sludge from two STSs in São Paulo State, Brazil. All of these studies and the current one reported high contents of organic matter and nutrients in sewage sludge, mainly N and P. Sampaio (2010), analyzing sludge produced in different STSs in Brazil, found contents of $\mathrm{N}$ ranging from 22.5 to $55.3 \mathrm{~g} \mathrm{~kg}^{-1}, \mathrm{P}$ from 6 to $30 \mathrm{~g} \mathrm{~kg}^{-1}, \mathrm{~K}$ from 0.1 to $3.9 \mathrm{~g} \mathrm{~kg}^{-1}$, and organic matter from 410 to $713 \mathrm{~g}$ $\mathrm{kg}^{-1}$. Thus, in general, the analyzed sludge lots are within the observed patterns for sludge generated in Brazilian stations.

In addition, the difference in nutrient concentration among the sludge is related not only to the composition of sewage generated in the drainage basin but also to the treatment type used at each STS. The STS Barra da Tijuca, for instance, has treatment at a primary level, which, according to Bielschowsky (2014), tends to generate sludge with lower nutrient concentrations than that produced in STS with secondary treatment, as in the other sludges analyzed in this study. Another fact observed was the variability of $\mathrm{N}$ content in the sludge from STS Ilha do Governador. This variability possibly occurred as a function of drying method by means of open-air semipermeable beds, which may have favored the percolation and volatilization of $\mathrm{N}$ when it remained for long periods in the drying process.

Sewage sludge lots analyzed presented $\mathrm{N}$ contents varying from 14.24 to $42.33 \mathrm{~g} \mathrm{~kg}^{-1}$ of sewage sludge on the dry basis (Table 1). Carvalho et al. (2015), analyzing five different sludge from STSs in São Paulo, Brazil, found similar N contents, which ranged from 17.40 to $42.63 \mathrm{~g} \mathrm{~kg}^{-1}$ on the dry basis. In the sewage sludge, the largest 
$\mathrm{N}$ portion is in an organic form and, therefore, it is readily available for plants only after organic matter degradation (CARVALHO et al., 2015; NASCIMENTO, 2016). This characteristic causes the $\mathrm{N}$ present in sewage sludge to be released slowly into the system, which may be favorable when compared to chemical fertilizers. Considering the strong Brazilian dependence on $\mathrm{N}$ import and relatively high costs for its acquisition, recycling of sludge and, consequently, $\mathrm{N}$ contained in it can be not only an environmental strategy but also a relevant economic strategy (ANDRADE et al., 2010).

Table 1. Nutrient and organic matter contents $\left(\mathrm{mg} \mathrm{kg}^{-1}\right)$ present in sludge lots of sewage treatment stations in the metropolitan area of Rio de Janeiro, RJ, Brazil.

\begin{tabular}{ccccccccc}
\hline STS & Lot & $\mathrm{N}$ & $\mathrm{P}$ & $\mathrm{K}$ & $\mathrm{Ca}$ & $\mathrm{Mg}$ & $\mathrm{MO}$ & $\mathrm{pH}$ \\
\hline Alegria & I & 38,83 & 6,16 & 5,00 & 2,36 & 0,15 & 544,1 & 5,5 \\
Alegria & II & 32,94 & 9,56 & 3,99 & 2,11 & 5,45 & 572,8 & 5,1 \\
Barra & III & 18,37 & 8,91 & 2,09 & 2,39 & 5,69 & 398,3 & 7,3 \\
Ilha & IV & 33,47 & 5,42 & 1,82 & 1,56 & 3,22 & 578,8 & 5,3 \\
Ilha & V & 28,78 & 5,22 & 1,57 & 1,74 & 3,22 & 589,4 & 5,0 \\
Ilha & VI & 14,24 & 5,53 & 4,01 & 18,51 & 5,83 & 598,7 & 6,5 \\
Sarapuí & VII & 42,33 & 17,23 & 2,73 & 1,35 & 2,95 & 515,9 & 6,3 \\
Sarapuí & VIII & 39,81 & 12,24 & 3,07 & 8,59 & 2,69 & 513,2 & 6,5 \\
\hline Mean & - & 31,09 & 8,78 & 3,03 & 4,83 & 3,65 & 538,9 & 5,8 \\
SD & - & 10,17 & 4,24 & 1,21 & 6,01 & 1,93 & 65,3 & 0,9 \\
\hline
\end{tabular}

$\mathrm{N}-$ Kjedhal method; $\mathrm{P}, \mathrm{Ca}$, and Mg-ICP-OES; K-flame photometry; OM-Walkley and Black method; $\mathrm{pH}-\mathrm{H}_{2} \mathrm{O}$. SD: standard deviation.

When analyzing the need to complement sewage sludge with nitrogen fertilizers for sugarcane fertilization, Chiba et al. (2008) found results that prove the efficiency of sludge in fertilizing this crop. The authors observed that a sludge dose corresponding to $120 \mathrm{~kg} \mathrm{ha}^{-1}$ of total $\mathrm{N}$ (10.8 tons) was enough to supply the requirements for sugarcane cultivation, without complementation with other nitrogen sources. Taking into account that sugarcane is the most cultivated agricultural crop in Rio de Janeiro, corresponding to approximately $49 \%$ of the total agricultural area cultivated in the state (EMATER, 2014); sludge reuse for fertilizing this crop can be one of the strategic alternatives for the state's agricultural sector.

$\mathrm{P}$ contents in the sludge lots analyzed ranged from 5.22 to $17.23 \mathrm{~g} \mathrm{~kg}^{-1}$, values close to those observed in other studies (CARVALHO et al., 2015; CONSUEGRA et al., 2015; MACHADO; TRANNIN, 2015; SAMPAIO, 2010). Sludge lots from STS Ilha do Governador presented the lowest P contents whereas STS Sarapuí presented the highest contents of this nutrient. Sewage sludge recycling for $\mathrm{P}$ reuse has a high economic and environmental potential since this is an essential element for all living organisms, being fundamental for food production. Thus, with the current rate of exploitation and use of $\mathrm{P}$, the estimation is that its reserves in the world will last for only 50 to 100 years (MARTÍNEZ et al., 2014).

In tropical and subtropical soils, as in Brazil, the dependence of phosphate fertilization is even more pronounced since $\mathrm{P}$ is strongly adsorbed in clay minerals, presenting a very low availability to plants, 
which requires the application of large amounts of phosphate fertilizers, most of which imported at a high cost (ANDRADE et al., 2010; MACHADO et al., 2011). Due to the decrease in quantity and quality of phosphate rocks, the tendency is that phosphorus gets increasingly expensive, which leads to an urgent need to seek new sources and develop sustainable methods for recycling this element, mainly through sewage sludge (EGLE et al., 2015; MARTÍNEZ et al., 2014).

$\mathrm{K}$ is a highly soluble substance, being found in lower concentrations in dry sewage sludge since this nutrient is diluted and solubilized in wastewater (BERTON; NOGUEIRA, 2010). The analyzed sludge presented $\mathrm{K}$ contents varying from 1.82 to $5.00 \mathrm{~g} \mathrm{~kg}^{-1}$, values close to those observed by Nascimento (2016), who analyzed sludge from 19 STSs in São Paulo State and found K contents varying from 0.50 to $4.60 \mathrm{~g} \mathrm{~kg}^{-1}$. Fuentes et al. (2010), Mtshali et al. (2014), and Suhadolc et al. (2010) also observed a low $\mathrm{K}$ content found in sewage sludge. Thus, for agricultural recycling, depending on crop requirements, sludge should be enriched with $\mathrm{K}$ sources.

$\mathrm{Ca}$ was found in contents ranging from 1.35 to $18.51 \mathrm{~g} \mathrm{~kg}^{-1}$ of sludge on a dry basis. In the studied STSs, liming treatment is not adopted for sludge cleaning, justifying these lower $\mathrm{Ca}$ contents in the sludge when compared to other studies (CARVALHO et al., 2015; CONSUEGRA et al., 2015; NASCIMENTO, 2016). Sludge from lot VI (STS Ilha do Governador), analyzed in January 2016, presented higher $\mathrm{Ca}$ content than the other samples, which may be the result of some punctual source of this nutrient in the drainage basin. According to Carneiro et al. (2005), the presence of calcium oxide can raise sewage sludge $\mathrm{pH}$ and favor losses through volatilization and leaching, which may explain the lower $\mathrm{N}$ contents in lot VI when compared to the other two lots from STS Ilha do Governador.
$\mathrm{Mg}$ contents found in the analyzed lots ranged from 0.15 to $5.83 \mathrm{~g} \mathrm{~kg}^{-1}$. Nascimento (2016), when analyzing the chemical composition of sludge from 19 STSs in São Paulo State, found $\mathrm{Mg}$ contents ranging from 1.0 to $4.5 \mathrm{~g} \mathrm{~kg}^{-1}$. This is an element present in the sludge essentially in a mineral form, i.e. inorganic, and even small sewage sludge doses can meet the needs for this nutrient depending on the crop demand (TSUTIYA, 2001).

The analyzed sludge presented organic matter content varying from 51.6 to $57.9 \%$. A high content of organic matter in the sludge generated in STSs is one of the main attributes to be taken into account for agricultural recycling of this material. Carvalho et al. (2015), when analyzing the organic fraction of five different sludge, found that more than $70 \%$ of carbon and $80 \%$ of nitrogen are in the organic compartment of sewage sludge. For this reason, sludge has been widely used as an amendment to improve soil chemical and physical characteristics and its application to soil has been indicated as one of the actions to mitigate climate change aiming at increasing the organic matter stock and hence soil carbon (BONINI et al., 2015; OUIMET et al., 2015).

Sewage sludge application is a beneficial alternative to recycle organic matter and nutrients as it improves soil physical, chemical, and biological properties, as well as improve vegetation establishment in degraded environments and assist the nutrition of agricultural crops (BORGES et al., 2009; LOBO et al., 2015; LU et al., 2012; SAMPAIO et al., 2016). However, before being used in agricultural crops and in addition to meeting the nutritional needs of plants and improving soil characteristics, sewage sludge needs to comply with the principles of environmental safety, with safe levels of heavy metals and offering no chemical or microbiological risk to human health or environment.

For all sewage sludge lots analyzed, concentrations of heavy metals were lower than the 
maximum allowed by legislation, characterizing them as viable for agricultural use regarding the risk of contamination by heavy metals (Table 2 ). Tiruneh et al. (2014) analyzed the chemical composition of sewage sludge from seven treatment stations in
Switzerland and found higher concentrations of heavy metals in sludge from STSs that received industrial sewage. The sludge analyzed in this study was from stations that receive only domestic loads, which justifies the low levels of heavy metals found.

Table 2. Contents of potentially toxic heavy metals $\left(\mathrm{mg} \mathrm{kg}^{-1}\right)$ in sludge lots of sewage treatment stations in the metropolitan area of Rio de Janeiro, RJ, Brazil.

\begin{tabular}{cccccccccccc}
\hline STS & Lot & $\mathrm{As}$ & $\mathrm{Ba}$ & $\mathrm{Cd}$ & $\mathrm{Cr}$ & $\mathrm{Cu}$ & $\mathrm{Hg}$ & $\mathrm{Ni}$ & $\mathrm{Pb}$ & $\mathrm{Se}$ & $\mathrm{Zn}$ \\
\hline Alegria & I & 2,6 & 157 & 0,20 & 70,1 & 267 & 0,03 & 40,2 & 197 & 5,9 & 681 \\
Alegria & II & 0,004 & 406 & 1,83 & 80,2 & 272 & 0,01 & 26,9 & 152 & 0,004 & 586 \\
Barra & III & 0,004 & 180 & 1,01 & 66,2 & 193 & 0,09 & 36,4 & 34 & 0,004 & 1007 \\
Ilha & IV & 3,65 & 182 & 1,29 & 42,7 & 240 & 0,02 & 16,2 & 71 & 0,004 & 675 \\
Ilha & V & 0,004 & 159 & 1,01 & 40,1 & 204 & 0,01 & 14,9 & 61 & 0,004 & 619 \\
Ilha & VI & 0,004 & 139 & 0,89 & 39,0 & 277 & 0,01 & 13,2 & 64 & 0,004 & 1079 \\
Sarapuí & VII & 0,004 & 567 & 0,99 & 55,3 & 117 & 0,01 & 11,1 & 39 & 0,004 & 366 \\
Sarapuí & VII & 0,004 & 41,1 & 0,19 & 20,3 & 23 & 0,01 & 11,2 & 6 & 0,004 & 43 \\
\hline Conama* & - & 41 & 1300 & 39 & 1000 & 1500 & 17 & 420 & 300 & 100 & 2800 \\
Mean & - & 0,8 & 228,9 & 0,9 & 51,7 & 199,1 & 0,02 & 21,3 & 78,0 & 0,74 & 632,0 \\
SD & - & 1,47 & 170,6 & 0,54 & 19,7 & 89,0 & 0,03 & 11,7 & 64,2 & 2,08 & 330,5 \\
\hline
\end{tabular}

*Maximum values of heavy metals present in the sludge allowed by CONAMA Resolution No. 375/2006.

Lots I and II, from STS Alegria, arouse the most attention because, although $\mathrm{Pb}$ contents are below the limit stipulated by legislation $\left(300 \mathrm{mg} \mathrm{kg}^{-1}\right)$, they represent 66 and $51 \%$ of the maximum limit, respectively. Considering that the STSs analyzed admit to receiving only domestic sewage, these $\mathrm{Pb}$ contents may indicate clandestine discharges in the sewage disposal system since the contents observed for these two samples are more similar to those observed in sludge from STSs that receive industrial loads than those exclusively domestic (PINHEIRO; SÍGOLO, 2007; TIRUNEH et al., 2014).

When analyzing the average concentration of heavy metals in the lots sampled regarding the maximum levels allowed by CONAMA Resolution No. 375/2006, the order of attention was $\mathrm{Pb}>\mathrm{Zn}>$ $\mathrm{Ba}>\mathrm{Cu}>\mathrm{Cr}>\mathrm{Ni}>\mathrm{Cd}>\mathrm{As}>\mathrm{Se}>\mathrm{Hg}$, which are respectively $26,23,18,13,5,2,2,1$, and $0,1 \%$ of the maximum limit for agricultural use. A concentration below the maximum limits allowed does not necessarily eliminate the risks of contamination since successive applications may lead to the accumulation of these metals in the agricultural soil (FJÄLLBORG et al., 2005).

Andrade et al. (2014) analyzed the heavy metal contents in two corn-cultivated Oxisols, which received thirteen annual applications of 5, 10, and $20 \mathrm{tha}^{-1}$ of sewage sludge, and found an increased content of heavy metals in the soil surface layer. Despite the fact that the contents were below the values determined by CONAMA Resolution No. 420/2009 (BRASIL, 2009), the authors warned that with more sludge application of heavy metal contents, these soils would reach a level of toxicity. Therefore, recycling of sewage sludge to agricultural crops that require successive applications requires 
constant monitoring to avoid negative effects.

Another important parameter is the analysis of pathogenic agents and bacteriological indicators, which are used to identify possible risks of microbiological contamination and classify sewage sludge in classes A or B. According to the data presented in Table 3, all sludge samples can be classified as belonging to class $\mathrm{A}$, indicating that pathogenic microorganism concentration in these materials is below the maximum allowed according to CONAMA Resolution No. 375/2006. Bittencourt (2014) observed the difficulty of analyzing the concentration of virus in sewage sludge in Brazil, where few laboratories perform the tests and methodologies for collection and analysis are complex and very costly, suggesting that the need for this analysis should be revised.

Table 3. Concentration of pathogenic microorganisms in sludge lots of sewage treatment stations in the metropolitan area of Rio de Janeiro, RJ, Brazil.

\begin{tabular}{ccccc}
\hline STS & Lot & $\begin{array}{c}\text { Thermotolerant } \\
\text { coliforms } \\
\left(\text { MLN g- }^{-1} \text { TS }\right)\end{array}$ & $\begin{array}{c}\text { Viable eggs of } \\
\text { helminths } \\
\left(\text { (egs g }^{-1} \mathrm{TS}\right)\end{array}$ & $\begin{array}{c}\text { Salmonella } \text { sp. } \\
\left.\text { (Present or absent in } 10 \mathrm{~g} \mathrm{TS}^{-1}\right)\end{array}$ \\
\hline Alegria & I & $<0,04$ & $<0,01$ & Absent \\
Alegria & II & $<0,04$ & $<0,01$ & Absent \\
Barra & III & $<0,04$ & $<0,01$ & Absent \\
Ilha & IV & 13,62 & $<0,01$ & Absent \\
Ilha & V & 7,29 & $<0,01$ & Absent \\
Ilha & VI & $<0,04$ & $<0,01$ & Absent \\
Sarapuí & VII & $<0,04$ & $<0,01$ & Absent \\
Sarapuí & VIII & $<0,04$ & $<0,01$ & Absent \\
\hline CONAMA* & - & $<1000$ & $<0,25$ & Absent \\
\hline
\end{tabular}

*Maximum values allowed by CONAMA Resolution No. 375/2006; MLN: most likely number; TS: Total solids.

For the use of sewage sludge on agricultural and forest areas, it should pass through a stabilization process to reduce pathogens, vector attraction potential elimination, and generation of odors (BRASIL, 2006). In spite of having different treatments, based on the results observed, treatment processes used by STSs have been efficient for sludge stabilization since all samples were below the maximum limits allowed by legislation.

Class A microbiological standards are the same as those set by the USA legislation, being a standard worldwide accepted for promoting the necessary public health safety of the exposed population. Although Brazilian legislation accepts the same parameters adopted worldwide, it makes severe restrictions on the application of class A sludge, even though there are no scientific and technical studies to justify it (SAMPAIO, 2010). Legislation in the United States and Australia does not impose restrictions on the use of class A sludge and it is even sold for domestic use in some USA supermarkets (SAMPAIO, 2010). In Brazil, the use of any type of sewage sludge in crops whose plant edible part is in contact with soil is expressly prohibited, as in root and tuber cultivation, in addition to some restrictions in relation to vegetables and pastures (BRASIL, 2006).

The analyzed sludges, in addition to presenting a high nutritional potential for agricultural use, were adequate to current legislation regarding the contents 
of heavy metals and biological contaminants. It is important to point out that, as can be observed from the presented data, sewage sludge composition has some variability from an STS to another mainly as a function of the drainage basin, the form of treatment used, and pathogen reduction method applied.

Table 4 presents the 10 most cultivated agricultural crops in Rio de Janeiro State, which represent $83 \%$ of the total cultivated area and $64.5 \%$ of annual agricultural revenues (EMATER, 2014). Among them, only cassava and lettuce could not be fertilized with sewage sludge considering the Article 12 ofCONAMAResolution No. 375/2006 (BRASIL, 2006), which prohibits sewage application in crops whose edible part is in direct contact with soil. The other crops are strategically important for future sewage sludge recycling actions since they present a potential demand of 2,902,943 tons of sewage sludge, which corresponds to approximately 22 times the annual production of sewage sludge from the entire state (PERS, 2014). Thus, all sewage sludge currently generated by STSs present in the state would meet only $4.59 \%$ of the potential demand for these eight agricultural crops. Literature findings have shown greater differences between the highest and the lowest sewage sludge recommended dose per hectare for sugarcane, banana, orange, and corn. Such fact can be attributed mainly to studies carried out in different conditions of climate, soil, genetic material, research methodologies, and mainly different sludges with different nutrient contents, directly influencing the recommendation to meet the nutritional crop demand.

Table 4. Potential demand for sewage sludge to be used in the 10 crops with the largest cultivated area in Rio de Janeiro State, Brazil.

\begin{tabular}{|c|c|c|c|c|c|}
\hline Crop & Area (ha) & $\begin{array}{l}\text { Recommendation* } \\
\left(\mathrm{t} \mathrm{ha}^{-1}\right)\end{array}$ & $\begin{array}{l}\text { Average recom- } \\
\text { mendation }\left(\mathrm{t} \mathrm{ha}^{-1}\right)\end{array}$ & $\begin{array}{l}\text { Potential de- } \\
\text { mand (tons) }\end{array}$ & Reference \\
\hline Sugarcane & 85.562 & $10,8-42$ & 22,75 & 1.946 .535 & $\begin{array}{l}\text { Chiba et al. (2009); Franco et al. } \\
\text { (2010); Silva et al. (1998) }\end{array}$ \\
\hline Banana & 14.604 & $9,0-52$ & 31,40 & 458.565 & $\begin{array}{l}\text { Barbosa (2008); Coelho et al. } \\
\text { (2011); Fortes (2011); Melo and } \\
\text { Ligo (2006) }\end{array}$ \\
\hline Coffee & 12.344 & $9,0-11,5$ & 10,25 & 126.526 & $\begin{array}{l}\text { Gonçalves (2005); Martins et al. } \\
\text { (2005) }\end{array}$ \\
\hline Cassava & 8.292 & - & - & 0 & Brasil (2006) \\
\hline Orange & 7.212 & $10,8-40$ & 18,36 & 132.412 & $\begin{array}{l}\text { Canet et al. (1997); Lambert } \\
\text { (2013); Lanza (2014); Romeiro } \\
\text { (2012); Romeiro et al. (2014) }\end{array}$ \\
\hline Lettuce & 4.497 & - & - & 0 & Brasil (2006) \\
\hline Green coconut & 3.613 & 12,87 & 12,87 & 46.499 & $\begin{array}{l}\text { Estimated by demand for } \mathrm{N} \text { by } \\
\text { culture }\end{array}$ \\
\hline Corn & 2.932 & $26-75$ & 46,50 & 136.338 & $\begin{array}{l}\text { Gomes et al. (2007); Junio et } \\
\text { al. (2011, 2013); Quintana et al. } \\
(2012)\end{array}$ \\
\hline Pineapple & 2.629 & 8,80 & 8,80 & 23.135 & Maia (2013) \\
\hline Tomato & 2.579 & 12,77 & 12,77 & 32.933 & Dantas (2010) \\
\hline Total & 144.264 & - & - & 2.902 .943 & - \\
\hline
\end{tabular}

*Highest and lowest recommendation found in the literature. 
Although sewage sludge has a high potential for agricultural recycling, it is necessary to identify the regions of greatest potential and deepen the logistics studies in order to verify the viability of transport to these areas. When analyzing the sewage sludge recycling program in Paraná State, Brazil, Bittencourt et al. (2014) observed that the distance between STS and application areas ranged from 32 to $213 \mathrm{~km}$, demonstrating the possibility of working at a regional level since not always the largest generators of sludge are the municipalities with the largest agricultural production.

Northern and northwestern Rio de Janeiro State are regions of a great agricultural importance, responsible for $63 \%$ of the state's cultivated agricultural area, with more than $94 \%$ of the area cultivated with sugarcane, almost $99 \%$ of pineapple, $83 \%$ of coffee, and $49 \%$ of green coconut (EMATER, 2014). In the northern region, Campos dos Goytacazes, São Francisco do Itabapoana, and Quissamã stand out producing sugarcane, pineapple, and green coconut. In the northwestern region, Porciúncula, Varre-sai, and Bom Jesus do Itabapoana stood out in growing coffee, corn, and sugarcane (EMATER, 2014). These crops could easily absorb all sewage sludge generated in the great cities of the region, such as Campos dos Goytacazes, Macaé, and Itaperuna since they have vast agricultural areas cultivated with species suitable for sewage sludge fertilization.

Some studies have demonstrated the advantages of fertilizing these crops with sewage sludge, such as improved soil quality, productivity gains, less dependence on chemical fertilizers, lower production costs, among others (CHIBA et al., 2009; FRANCO et al., 2010; JUNIO et al., 2013; MAIA, 2013; MARTINS et al., 2005; YADA et al., 2015). Sewage sludge recycling in these agricultural areas can represent considerable savings with chemical fertilizers, providing economic, environmental, and social benefits. Chiba et al. (2008) and Franco et al. (2010) analyzed the efficiency of sewage sludge in sugarcane fertilization and concluded that sludge can supply up to $100 \%$ of nitrogen fertilizer requirement. Since sugarcane is the main agricultural crop in Rio de Janeiro State, the use of sewage sludge as fertilizer should be treated as a strategic issue for the agricultural sector of Rio de Janeiro.

Another traditionally agricultural region is the Mountain Region, which is recognized as a large producer of vegetables and responsible for more than 90\% of lettuce production in the state (EMATER, 2014). Among the eight crops analyzed that are apt to receive sewage sludge, banana, coffee, tomato, and corn stand out in this region, with a total area of approximately 6,390 ha (EMATER, 2014). In addition to these crops, producers who practice fallow farming in this region could also use sewage sludge.

The fallow system can be defined as a form of agriculture marked by crop rotation of small areas for short periods (2 to 4 years) alternated with long periods of rest (5 to 10 years), showing a great historical and cultural representation in the Mountain Region of Rio de Janeiro (SILVA, 1996). In this system, the fallow time has an influence on environmental sustainability and economic viability because long periods of fallow to recuperate soil fertility can make the system unfeasible since it would require larger production areas, increasing the costs related to land clearing (CORREIA et al., 2004). Sewage sludge could be applied at the end of production cycle as a soil amendment, accelerating the recovery of soil chemical and physical characteristics during the fallow period, mainly organic matter, which is considered as one of the main quality indicators in this system (BENITES et al., 2010). With a less fallow time, production area can be optimized without the need to suppress new forest areas. According to legislation, soils that received sewage can be cultivated with any crop after 48 months. Thus, considering that fallow time varies from 5 to 10 years, there would be no restrictions on land use after this recovery period (BRASIL, 2006). 
Metropolitan region of Rio de Janeiro is extremely important for agricultural recycling of sewage sludge since it has the highest population density of the state and hence it presents the greatest potential for sewage sludge generation. Among the eight crops analyzed, banana and orange cultivation stand out mainly in Itaguaí, Paracambi, Seropédica, Tanguá, and Rio Bonito (EMATER, 2014), being located less than $90 \mathrm{~km}$ from Rio de Janeiro City and having together more than 6,000 ha cultivated with only banana and orange, presenting a great potential for agricultural recycling of sewage sludge generated in this metropolis. Sewage sludge recycling in these areas could bring benefits for both sanitation companies, which would reduce their disposal costs and dispose of their residues in a more sustainable way, and producers, who could increase their production and reduce input costs. Bittencourt et al. (2014) analyzed, from 2007 to 2010, the agricultural recycling of sewage sludge in Paraná State in more than 2200 hectares of agricultural areas and concluded that the 80 producers participating in the recycling program saved an average of US\$ $813.45 \mathrm{ha}^{-1}$ in fertilizers and soil amendments.

In the coastal lowland regions, Araruama, Silva Jardim, Cabo Frio, and Saquarema are important producers of orange, banana, sugarcane, and green coconut, the main crops of the region, with a total area of 8,746 ha (EMATER, 2014). Costa Verde region has a prominent role in the banana production, mainly in Mangaratiba, which accounts for almost $33 \%$ of the area cultivated with bananas in the state. Both regions could use in agricultural areas the sludge generated in their cities and that from the metropolitan region of Rio de Janeiro, close to them.

South central and middle Paraíba River regions have already been large agricultural producers, mainly during the coffee cycle, but currently have only $2.12 \%$ of the agricultural area cultivated in Rio de Janeiro State (EMATER, 2014). In the south central region, tomato is the largest crop cultivated in Paty do Alferes and Vassouras. In the middle Paraíba River region, banana stands out in Piraí and sugarcane in Rio Claro and Valença. Larger cities, but without large agricultural areas such as Resende and Volta Redonda, could use sewage sludge recycling in partnership with smaller cities, which have larger agricultural areas but do not generate large amounts of sludge.

In addition to economic benefits, agricultural recycling of sewage sludge also brings environmental advantages such as the mitigation of greenhouse gases by reducing chemical fertilizers and increasing soil carbon stock, as well as increase of soil biological diversity, reuse of nutrients (mainly $\mathrm{N}$ and $\mathrm{P}$ ), and reduction residue disposal in landfills, increasing their useful life (LOZADA et al., 2015; OUIMET et al., 2015). In order to guarantee these environmental benefits, the locational restrictions contained in the Article 15 of CONAMA Resolution No. 375/2006 must be respected, thus minimizing the risks to the environment and human health (BRASIL, 2006). In this sense, more in-depth studies are needed aiming at spatially demarcating apt areas for sewage sludge application and identifying the use and occupation of soil in these areas, which would bring more data to subsidize the recycling programs.

\section{Conclusions}

The analyzed sludge presented a high content of nutrients and organic matter and was included in the parameters of heavy metals, pathogenic agents, and bacteriological indicators stipulated by CONAMA Resolution No. 375/2006. All sludge samples were classified as class A, with favorable attributes for agricultural recycling.

The agricultural panorama of Rio de Janeiro State is favorable for agricultural recycling of sewage sludge with a great potential demand. Furthermore, among the 10 agricultural crops with the largest cultivated area in the state, sludge can be used as fertilizer or soil amendment in eight of them. The implementation of a State Sewage Sludge 
Recycling Program could dispose of this material in a more sustainable way, as well as improve the quality of agricultural soils and reduce costs with chemical fertilizers, bringing about positive results for sanitation companies and producers.

\section{Acknowledgements}

The authors are grateful to the State Water and Sewage Company of Rio de Janeiro (CEDAE) and to the Graduate Program in Environmental and Forestry Sciences of UFRRJ for both support and incentive to research.

\section{References}

ABREU, A. H. M. Biossólido na produção de mudas florestais da Mata Atlântica. 2014. Dissertação (Mestrado em Ciências Ambientais e Florestais) - Universidade Federal Rural do Rio de Janeiro, Seropédica.

AGUILERA, S. M.; BORIE, G.; PEIRANO, P.; RODRÍGUEZ, M.; GREZ, I.; ZUNINO, H. Chemical characterization of sewage sludges in Chile and their potential utilization as amendment to reclaim soils for forestation purposes. Journal of Plant Nutrition, Philadelphia, v. 30, n. 12, p. 1993-2003, 2007.

ANDRADE, C. A.; BOEIRA, R. C.; PIRES, A. M. M. Nitrogênio presente em lodo de esgoto e a resolução $n^{\circ}$ 375 do CONAMA. In: COSCIONE, A. R.; NOGUEIRA, T. A. R.; PIRES, A. M. M. (Org.). Uso agrícola de lodo de esgoto: avaliação após resolução $\mathrm{n}^{\circ} 375$ do CONAMA. Botucatu: FEPAF, 2010. p. 157-170.

ANDRADE, M. G.; LIMA, A. S. T.; MELO, W. J.; SANTOS, E. J.; HERRMANN, A. B. Elementos-traço em dois latossolos após aplicações anuais de lodo de esgoto por treze anos. Semina: Ciências Agrárias, Londrina, v. 35, n. 1, p. 135-148, 2014.

BARBOSA, R. D. Manejo de solo com lodo de esgoto em bananeira irrigada. 2008. Tese (Doutorado em Agronomia) - Universidade Estadual Paulista Júlio de Mesquita Filho, Botucatu.

BENITES, M. V.; MOUTTA, R. O.; COUTINHO, H. L. C.; BALIEIRO, F. C. Análise discriminante de solos sob diferentes usos em área de mata atlântica a partir de atributos da matéria orgânica. Árvore, Viçosa, MG, v. 34, n. 1, p. 685-690, 2010.

BERTON, R. S.; NOGUEIRA, T. A. R. Uso de lodo de esgoto na agricultura. In: COSCIONE, A. R.; NOGUEIRA, T. A. R.; PIRES, A. M. M. Uso agrícola de lodo de esgoto: avaliação após a resolução $\mathrm{n}^{\circ} 375$ do CONAMA. Botucatu: FEPAF, 2010. cap. 2, p. 31-50.

BIELSCHOWSKY, M. C. Modelo de gerenciamento de lodo de estação de tratamento de esgotos: aplicação do caso da Bacia da Baía de Guanabara. 2014. Dissertação (Mestrado em Engenharia Ambiental) - Universidade Federal do Rio de Janeiro, Rio de Janeiro.

BITTENCOURT, S. Gestão do processo de uso agrícola de lodo de esgoto no Estado do Paraná: aplicabilidade da resolução Conama n⿳30375/2006. 2014. Tese (Doutorado Engenharia de Recursos Hidrícos e Ambiental) Universidade Federal do Paraná, Curitiba.

BITTENCOURT, S.; SERRAT, B. M.; AISSE, M. M.; GOMES, D. Sewage sludge usage in agriculture: a case study of its destination in the Curitiba Metropolitan REGION, Paraná, Brazil. Water Air and Soil Pollution, Dordrecht, v. 225, p. 1-8, 2014.

BONINI, C. S. B.; ALVES, M. C.; MONTANARI, R. Lodo de esgoto e adubação mineral na recuperação de atributos químicos de solo degradado. Revista Brasileira de Engenharia Agrícola e Ambiental, Campina Grande, v. 19, n. 4, p.388-393, 2015.

BORGES, T. A.; SILVA, C. M.; BALDUÍNO, A. P. C.; SOARES, J. A.; PEREIRA, C. E. B. Uso de lodo de esgoto na recuperação de área degradada no Distrito Federal. Revista AIDIS, Juriquilla, v. 2, n. 1, p. 65-75, 2009.

BOURIOUG, M.; GIMBERT, F.; ALAOUI-SEHMER, L.; BENBRAHIM, M.; ALEYA, L.; SOSSÉ, B. A. Sewage sludge application in a plantation: Effects on trace metal transfer in soil-plant-snail continuum. Science of the Total Environment, Califórnia, v. 503, p. 309-314, 2015.

BRASIL. Lei $\mathrm{n}^{\circ} 12.305$ de 02 de agosto de 2010. Institui a Política Nacional de Resíduos Sólidos; altera a Lei no 9.605, de 12 de fevereiro de 1998; e dá outras providências. Diário Oficial [da] República Federativa do Brasil, Brasília, 03 de agosto de 2010. Seção 1, p. 3.

Ministério das Cidades. Secretaria Nacional de Saneamento Ambiental-SNSA. Sistema nacional de informações sobre saneamento: Diagnóstico dos Serviços de Água e Esgotos-2014. Brasília: SNSA/MCIDADES, 2016. 212 p.

- Ministério do Meio Ambiente. Conselho Nacional do Meio Ambiente. Resolução-CONAMA. Resolução no 375/2006. Define critérios e procedimentos para o uso agrícola de lodos de esgoto gerados em estações de tratamento de esgoto sanitário e seus produtos 
derivados. Diário Oficial [da] República Federativa do Brasil, Brasília, 30 ago 2006, n. 167, p. 141-146,

Ministério do Meio Ambiente. Conselho Nacional do Meio Ambiente. Resolução-CONAMA. Resolução no 420/2009. Diário Oficial [da] República Federativa do Brasil, Brasília, 30 de dezembro de 2009. Disponível em: <http://www.mma.gov.br/port/conama/ legiabre.cfm.htm>. Acesso em: 20 maio 2016.

CANET, R.; POMARES, F.; TARAZONA, F. Chemical extractability and availability of heavy metals after seven years application of organic wastes to a citrus soil. Soil Use and Management, Aberdeen, v. 13, n. 3, p. 117-121, 1997.

CARMO, D. L.; SILVA, C. A. Métodos de quantificação de carbono e matéria orgânica em resíduos orgânicos. Revista Brasileira de Ciências do solo, Viçosa, MG, v. 36, n. 4, p. 1211-1220, 2012.

CARNEIRO, C.; SOTTOMAIOR, A. P.; ANDREOLI, C. V. Dinâmica de nitrogênio em lodo de esgoto sob condições de estocagem. Revista Brasileira de Ciências do Solo, Viçosa, MG, v. 29, n. 6, p. 987-994, 2005.

CARVALHO, C. S.; RIBEIRINHO, V. S.; ANDRADE, C. A.; GRUTZMACHER, P.; PIRES, A. M. M. Composição química da matéria orgânica de lodos de esgoto. Revista Brasileira de Ciências Agrárias, Recife, v. 10, n. 3, p. 413-419, 2015.

CHIBA, M. K.; MATTIAZZO, M. E.; OLIVEIRA, F. C. Cultivo de cana de açúcar em Argissolo tratado com lodo de esgoto. I-disponibilidade de nitrogênio no solo e componentes de produção. Revista Brasileira de Ciências do Solo, Viçosa, MG, v. 32, n. 2, p. 643-652, 2008.

CHIBA, M. K.; MATTIAZZO, M. E.; OLIVEIRA, F. C. Rendimento de cana de açúcar cultivada em Argissolo, utilizando lodo de esgoto como fonte de fósforo. Acta Scientiarum Agronomy, Maringá, v. 31, n. 3, p. 495-501, 2009.

COELHO, H. A.; GRASSI FILHO, H.; ROMEIRO, J. C. T.; POMPERMAYER, G. V.; BARBOSA, R. D.; LOBO, T. F. Desempenho agronômico do lodo de esgoto como fonte de nitrogênio em bananeiras. Revista Agrarian, Dourados, v. 4, n. 13, p. 172-181, 2011.

CONSUEGRA, S. B. M.; NAVARRO, F. J. G.; VILLAJOS, J. A. A. O.; REYES, C. P.; HIGUERAS, P. L. Effect of the addition of sewage sludge as a fertilizer on a sandy vineyard soil. Jornal of Soils and Sediments, Berlin, v. 23, n. 2, p. 151-157, 2015.

CORREIA, M. E. F.; REIS, L. L.; CAMPELLO, E. F. C.; FRANCO, A. A. Populações da macrofauna do solo em agricultura itinerante na região da Mata Atlântica, RJ. In: CAMPELLO, E. F. C. (Ed.). Seminário sobre
Agricultura Migratória na Região Serrana do Rio de Janeiro. Seropédica: EMBRAPA-Agrobiologia, 2004. p. $62-75$.

DANTAS, J. D. M. Uso de lodo de esgoto como fonte alternativa de nitrogênio para o cultivo do tometeiro cereja (Lycopersicumesculentumsp.). 2010. Dissertação (Mestrado em Agroecossistemas) - Universidade Federal de Sergipe, São Cristovão.

EGLE, L.; RECHBERGER, H.; ZESSNER, M. Overview and description of technologies for recovering phosphorus from municipal wastewater resources, conservation and recycling. Resources, Conservation and Recycling, Aberdeen, v. 105, p. 325-346, 2015. Available at: <http://dx.doi.org/10.1016/j.resconrec.2015.09.016>. Accessed at: 21 jun. 2016.

EMPRESA DE ASSISTÊNCIA TÉCNICA E EXTENSÃO RURAL DO RIO DE JANEIRO EMATER. Acompanhamento sistemático da produção agrícola. Rio de Janeiro: EMATER, 2014. Available at: $\quad<$ http://www.emater.rj.gov.br/images/ASPA2014 MUN_SITE.htm>. Accessed at:24 maio 2016.

FJÄLlBORG， B.; AHLBERG，G.; NILSSON， E.; DAVE, G. Identification of metal toxicity in sewage sludge leachate. Environment International, v. 31, n. 1, p. 25-31, 2005.

FORTES, F. C. A. Manejo do solo com lodo de esgoto na produção e qualidade de frutos em bananeira irrigada. 2011. Tese (Doutorado em Agronomia) - Universidade Estadual Paulista Julio de Mesquita Filho, Botucatu.

FRANCO, A.; ABREU JUNIOR, C.H.; PERECIN, D.; OLIVEIRA, F. C.; GRANJA, A. C. R.; BRAGA, V. S. Sewage sludge as nitrogen and phosphorus source for cane-plant and first ratoon crops. Revista Brasileira de Ciências do Solo, Viçosa, v. 34, n. 2, p. 553-561, 2010.

FUENTES, D.; VALDECANTOS, A.; LLOVET, J.; CORTINA, J.; VALLEJO, V. R. Fine-tuning of sewage sludge application to promote the establishment of Pinus halepensis seedlings. Ecological Engineering, warsaw, v. 36, n. 10, p. 1213-1221, 2010.

GOMES, S. B. V.; NASCIMENTO, C. W. A.; BIONDI, C. M. Produtividade e composição mineral de plantas de milho em solo adubado com lodo de esgoto. Revista Brasileira de Engenharia Agrícola e Ambiental, Campina Grande, v. 11, n. 5, p. 459-465, 2007.

GONÇALVES, F. T. A. Dinâmica do nitrogênio em solo tratado com lodo de esgoto e cultivado com café. 2005. Dissertação (Mestrado em Gestão de Recursos Agroambientais) - Instituto Agronômico de Campinas, Campinas.

JUNIO, G. R. Z.; SAMPAIO, R. A.; NASCIMENTO, A. 
L.; SANTOS, G. S.; SANTOS, L. D. T.; FERNANDES, L. A. Produtividade de milho adubado com composto de lodo de esgoto e fosfato natural de gafsa. Revista Brasileira de Engenharia Agrícola e Ambiental, Campina Grande, v. 17, n. 7, p. 706-712, 2013.

JUNIO, G. R. Z.; SAMPAIO, R. A.; SANTOS, G. B.; NASCIMENTO, A. L.; PRATES, F. B. S.; FERNANDES, L. A. Metais pesados em milho fertilizado com fosfato natural e composto de lodo de esgoto. Revista Brasileira de Engenharia Agrícola e Ambiental, Campina Grande, v. 15, n. 10, p. 1082-1088, 2011.

LAMBERT, R. A. Eficiência do uso de água residuaria e de lodo de esgoto compostado nas propriedades químicas e físicas de solo cultivados com laranjeiras. 2013. Tese (Doutorado em Irrigação e Drenagem) - Universidade Estadual Paulista Julio de Mesquita Filho, Botucatu.

LANZA, M. H. Utilização de lodo de esgoto compostado e irrigação com água residuária em laranjeiras valência. 2014. Dissertação (Mestrado em Irrigação e Drenagem) Universidade Estadual Paulista Julio de Mesquita Filho, Botucatu.

LOBO, T. F.; GRASSI FILHO, H.; BULL, L. T.; SOUZA, F. L. P. Efeito do nitrogênio e do lodo de esgoto na nutrição do feijoeiro. Revista Verde de Agroecologia e Desenvolvimento Sustentável, Pombal, v. 10, n. 2, p. 33-41, 2015.

LOZADA, P. T.; LEAL, J. A. S.; OROBIO, B. A. P.; CASTRO, V. C.; PARRA, C. A. M. Influencia de La aplicación de biosólidos sobre el suelo, la morfologia y productividad del cultivo de caña de azúcar. Revista Universidad de Ciencias Aplicadas y Ambientales Actualidad \& Divulgación Científica, Cartagena, v. 18, n. 1, p. 69-79, 2015.

LU, Q.; HE, Z. L.; STOFFELLA, P. J. Land application of biosolids in the USA: a review. Applied and Environmental Soil Science, Cairo, v. 2012, p. 1-11, 2012.

MACHADO, L. R. D.; TRANNIN, I. C. B. Agricultural potential of na industrial sewage sludge in compliance with CONAMA Resolution $\mathrm{n}^{\circ}$ 375/2006. Semina: Ciências Agrárias, Londrina, v. 36, n. 6, p. 4177-4184, 2015.

MACHADO, V. J.; SOUZA, C. H. E.; ANDRADE, B. B.; LANA, R. M. Q. Curvas de disponibilidade de fósforo em solos com diferentes texturas após aplicação de doses crescentes de fosfato monoamônico. Bioscience Jornal, Uberlândia, v. 27, n. 1, p. 70-76, 2011.

MAIA, F. G. Efeito da adubação com lodo de esgoto nas características químicas do solo, desenvolvimento vegetativo, produtividade e qualidade de frutos de abacaxizeiro cv. Vitória. 2013. Dissertação (Mestrado em Biologia Vegetal) - Universidade Federal do Espirito Santos, Vitória.

MARTÍNEZ, A. A.; GEA, G.; ARAUZO, J.; KERSTEN, S. R. A.; KOOTSTRA, A. M. J. Phosphorus recovery from sewage sludge char ash. Biomass and Bioenergy, Amsterdam, v. 65, p. 42-50, 2014.

MARTINS, D. R.; CAMARGO, O. A.; BATAGLIA, O. C. Qualidade do grão e da bebida em cafeeiros tratados com lodo de esgoto. Bragantia, Campinas, v. 64, n. 1, p. 115-126, 2005.

MELO, L. A. S.; LIGO, M. A. V. Uso de lodo de esgoto em bananicultura: efeitos de doses no primeiro ano de aplicação. Revista Cientiae Rural, Ponta Grossa, v. 11, n. 2, p. 33-38, 2006.

MININNI, G.; BLANCH, A. R.; LUCENA, F.; BERSELLI, S. EU policy on sewage sludge utilization and perspectives on new approaches of sludge management. Environmental Science and Pollution Research, Coimbatore, v. 22, n. 10, p. 7361-7374, 2015.

MITSHALI, J. S.; TIRUNEH, A. T.; FADIRAN, A. $O$. Characterization of sewage sludge generated from wastewater treatment plants in swaziland in relation to agricultural uses. Resources and Environment, Bodh Gaya, v. 4, n. 4, p. 190-199, 2014.

NASCIMENTO, A. L. Caracterização microbiológica, química e presença de poluentes orgânicos em amostras de lodo de esgoto de São Paulo. 2016. Tese (Doutorado em Ciências) - Escola Superior de Agricultura Luiz de Queiroz, Piracicaba.

OUIMET, R.; PION, A. P.; HÉBERT, M. Long-term response of forest plantation productivity and soils to a single application of municipal biosolids. Canadian Journal Soil Science, Saskatoon, v. 95, n. 2, p. 187-199, 2015.

PINHEIRO, C. H. R.; SíGOLO, J. B. Metais pesados e elementos associados do lodo de esgoto da ETE BarueriRegião metropolitana de São Paulo diante do fator sazonalidade. Geochimica Brasiliensis, São Paulo, v. 21, n, 2, p. 148-164, 2007.

PLANO ESTADUAL DE RESÍDUOS SÓLIDOS DO RIO DE JANEIRO - PERS. Rio de Janeiro: SEA / INEA, 2014. $137 \mathrm{p}$.

PRITCHARD, D. L.; PENNEY, N.; MCLAUGHLIN, M. J.; RIGBY, H.; SCHWARZ, K. Land application of sewage sludge (biosolids) in Australia: risks to the environment and food crops. Water Science \& Technology, London, v. 62, n. 1, p. 48-57, 2010.

QUINTANA, N. R. G.; MELO, W. J.; CARMO, M. S. Rentabilidade efetiva e rentabilidade total do cultivo de 
milho adubado com lodo de esgoto. Nucleus, Ituverava, v. 9, n. 2, p. 281-288, 2012.

ROMEIRO, J. C. T.; GRASSI FILHO, H.; MOREIRA, L. L. Q. Absorção de N, P, K, Ca e Mg por laranjeiras Pera fertilizadas com lodo de esgoto compostado em substituição à adubação nitrogenada mineral. Irriga, Botucatu, v. 19, n. 1, p. 82-93, 2014.

ROMEIRO, J. C. T. Atributos químicos do solo e crescimento de laranjeiras 'Pera' irrigadas com efluente de esgoto tratadoe fertilizadas com lodo de esgoto compostado. 2012.Tese (Doutorado em Agrônomia) Universidade Estadual Paulista Júlio de Mesquita Filho, Botucatu.

SAMPAIO, A. O. Adequação das estações de tratamento de esgotos sanitários à resolução número 375 do CONAMA. In: COSCIONE, A. R.; NOGUEIRA, T. A. R.; PIRES, A. M. M. Uso agrícola de lodo de esgoto: avaliação após a resolução $n^{\circ} 375$ do CONAMA. Botucatu: FEPAF, 2010. p. 265-278.

SAMPAIO, T. F.; GUERRINI, I. A.; OTERO, X. L.; VAZQUEZ, F. M.; BOGIANI, J. C.; OLIVIEIRA, F. C.; MARCIA, J. L. G.; CIOL, M. A.; LITTKE, K. M.; HARRISON, R. B. The impact of biosolid application on soil and native plants in a degraded brazilian atlantic rain forest soil. Water Air and Soil Pollution, v. 227, n. 1, p. 1-10, 2016.

SILVA, F. C.; BOARETTO, A. E.; BERTON, R. S.; ZOTELLI, H. B.; PEXE, C. A.; MENDONÇA, E. Cana de açúcar cultivada em solo adubado com lodo de esgoto: nutrientes metais pesados e produtividade. Pesquisa Agropecuária Brasileira, Brasília, v. 33, n. 1, p. 1-8, 1998.

SILVA, L. F. Solos tropicais: aspectos pedológicos, ecológicos e de manejo. São Paulo: Terra Brasilis, 1996. $123 \mathrm{p}$.

SUHADOLC, M.; SCHOLL, R.; HANG, A.; DORFLER, U.; SCHLOTER, M.; LOBNIK, F. Single application on of sewage sludge- impact on the quality of an alluvial agricultural soil. Chemosphere, Aberdeen, v. 81, n. 11, p. 1536-1543, 2010.

TIRUNEH, A. T.; FADIRAN, A. O.; MTSHALI, J. S. Evaluation of the risk of heavy metal in sewage sludge intended for agricultural application in Swaziland. International Journal of Envrironmental Sciences, New York, v. 5, n. 1, p. 197-216, 2014.

TSUTIYA, M. T. Biossólidos na agricultura. São Paulo: SABESP, 2001. 113 p.

UNITED STATE ENVIRONMENT PROTECTION AGENCY - USEPA. SW-846. Test methods for evaluating solid waste, physical chemical methods. Washington: USEPA, 2010. Available at: <http:/www. epa.gov/epaoswer/hazwaste/test/main.htm\#table $>$. Accessed at: 7 may 2014.

YADA, M. M.; MELO, W. J.; MINGOTE, F. L. C.; MELO, V. P.; MELO, G. M. P. Chemical and biochemical propertiers of Oxisols after sewage sludge application for 16 years. Revista Brasileira de Ciências do Solo, Viçosa, MG, v. 30, n. 5, p. 1302-1310, 2015. 
